DOI: $10.17976 / \mathrm{jpps} / 2017.03 .07$

\title{
СИСТЕМЫ ДОМИНАНТНЫХ ПАРТИЙ: НЕКОТОРЫЕ ПОДХОДЫ К МЕТОДОЛОГИИ ИССЛЕДОВАНИЯ
}

\section{Д.В. Стрельцов}

СТРЕЛЬЦОВ Дмитрий Викторович, доктор исторических наук, профессор, зав. кафедрой востоковедения МГИМО МИД России. Для связи с автором: d.streltsov@inno.mgimo.ru

Стрельцов Д.В. Системы доминантных партий: некоторые подходы к методологии исследования. Полис. Политические исследования. 2017. № 3. С. 105-118. DOI: https://doi.org/10.17976/jpps/2017.03.07

Исследование выполнено при финансовой поддержке РГНФ (проект № 16-01-50085 “'Система 1955 года': политическая власть в Японии в эпоху холодной войны”)

Статья поступила в редакцию: 10.10.2016. Принята к печати: 01.02.2017

Аннотация. В статье рассмотрены такие ключевые критерии понятия доминантной партии, как ее способность последовательно и стабильно побеждать на выборах, длительность пребывания у власти, а также кадровый контроль в отношении кабинета министров. В общественно-политическом дискурсе доминантная партия занимает привилегированное идеологическое поле и имеет более широкие возможности апеллирования к избирателям, чем ее конкуренты. При этом доминантность партии проявляется не только внешне (нахождение у власти), но и внутренне - через способность осуществлять эффективный политический выбор. Проанализированы факторы устойчивости системы доминантной партии: исторические заслуги партии власти; способность правящей партии эффективно использовать преимущества избирательной системы; прочные связи с наиболее обеспеченными социальными группами и крупнейшими корпорациями, с превалирующей этнической или языковой социальной группой; привилегированный доступ партии власти к медиа-ресурсам. Перечисленные факторы проявляются и в недоминантных (полицентрических) политических системах. Однако для систем доминантных партий характерно то, что они действуют в совокупности, предоставляя партии власти многослойную защиту за счет кумулятивного эффекта. Отдельное внимание уделяется феномену клиентелистской политики, которая активно применяется партией власти в качестве стратегии политической мобилизации. В условиях, когда масштабы и процессы партикуляристской политики делают этот феномен общественно значимым и, соответственно, подверженным публичному контролю, данная практика отвечает стандартам демократического процесса, даже несмотря на те негативные эффекты, которые клиентелизм может оказывать на общественное благо. Вместе с тем, если привносимая клиентелизмом дискриминация достигает такого уровня интенсивности, который лишает клиентов права выбора, это уже не соответствует нормам демократии.

Ключевые слова: доминантные партии; клиентелизм; партикуляристская политика; конкуренция; демократия; доступ к ресурсам; патронаж; значимые выборы; контекстуально встроенный феномен.

Более полувека огромное внимание в политической науке уделяется феномену доминантных партий, и для этого имеются серьезные основания. Авторитарные системы, основанные на длительной власти одной партии, получили в мире достаточно широкое распространение, причем не только 
в странах афроазиатского мира. Даже в демократических странах Запада оказались востребованными партийно-политические системы, где заметно проявляло себя доминирование одной политической силы - наиболее известными примерами явились Япония и Италия.

Наиболее стабильной и долгосрочной формой существования авторитарных режимов были системы однопартийного правления. Практика показала наличие большого разнообразия партий и политических организаций, занимавших ключевые места в политических системах: Гоминьдан на Тайване, Африканский национальный конгресс в ЮАР, Социал-демократическая партия Швеции, ЛДП в Японии, ХДС в Италии, Индийский национальный конгресс в Индии. Задача теоретического обобщения феномена доминантных партий особенно актуализируется в современной России, где данный феномен проявляет себя активно на протяжении практически всего постсоветского периода.

Огромное многообразие режимов доминантной партии наблюдалось в идеологической, институциональной, государственно-управленческой и иных сферах. Это дало Т. Пемпелю основания для вывода о том, что один и тот же институциональный контейнер, а именно доминантная партия, может иметь различное содержание в зависимости от специфики политической системы, в которой эта партия создана [Pempel 1999: VIII]. Он указывал, что в одних исторических обстоятельствах "реальная демократизация проводилась доминантными партиями, в других, наоборот, однопартийное правление выступало, скорее, препятствием для демократизации, нежели фактором в его пользу" [ibid.: VII].

Широкий диапазон вариативности, наблюдаемый при анализе форм и содержания систем доминантных партий, существенно затрудняет процесс их типизации и классификации. Так, невозможно выделить единые критерии, касающиеся условий зарождения систем доминантных партий: иногда речь может идти о серьезных кризисах общественного развития, выразившихся в революциях, гражданских войнах, государственных переворотах и т.д., а иногда подобные системы формируются в относительно спокойных условиях.

С трудом поддаются теоретическому обобщению и формальные характеристики политического режима доминантных партий, включая электоральную систему и индикаторы социального развития, показатели политического влияния партии власти на начальном этапе ее политического доминирования, влияние доминантности на политическую культуру и национально-психологические особенности социума. В современном научном дискурсе отсутствует единство мнений не только в отношении того, почему определенная партия становится доминирующей в той или иной политической системе и каковы механизмы поддержания ее доминантного положения, но даже в отношении того, какие партии вообще следует считать доминантными.

\section{КРИТЕРИИ ДОМИНАНТНОЙ ПАРТИИ}

Несмотря на разнобой в определении доминантных партий, можно выделить ряд общих критериев в подходе к этому феномену. Прежде всего, в демократических режимах доминантные партии находятся у власти при соблюдении определенных электоральных процедур, в связи с чем на первый 
план выходит их способность последовательно и стабильно побеждать на выборах. По мнению Р. Зуттнера, электоральные успехи и отсутствие серьезных перспектив поражения на выборах - одна из ключевых характеристик доминантной партии [Suttner 2006: 277]. Сходным образом оценивает систему доминантной партии и Дж. Сартори, который считает, что крупнейшая партия в таких системах постоянно получает поддержку избирателей, приносящую ей победу на выборах [Sartori 1976: 192-201].

Другим распространенным критерием систем доминантных партий выступает длительность пребывания таких партий у власти. Доминантными принято называть те партии, которые в течение длительного времени побеждают на общенациональных выборах, обеспечивая себе право формирования правительства [Сох 1997: 238]. Относительно критериев длительности пребывания у власти имеются различные точки зрения: некоторые исследователи считают, что на право именоваться “доминантной” могут претендовать партии, которые одерживали победу в трех предвыборных циклах подряд, некоторые что речь может идти о пребывании у власти как минимум в течение четырех предвыборных циклов, или двадцати лет [Greene 2010a: 809]. Исторический опыт (в частности, завершение эпохи “системы 1955 года” в Японии в 1993 г. или власти КПСС в 1991 г.) показывает, что доминантные партии не могут править бесконечно.

Контроль доминантной партии в отношении исполнительной власти являет собой следующую ключевую характеристику доминантности. В кабинетно-парламентских системах доминантность предполагает обладание одной партией креслом премьер-министра, как минимум половиной мест в парламенте, а также положение, при котором формирование правительства без такой партии оказывается невозможным [O’Leary 1994]. При этом доминантная партия занимает ключевое положение в политической системе страны даже в том случае, если она делит власть с иными партиями, входящими в правящую коалицию. Иными словами, даже если доминантная партия лишается большинства в законодательном органе, оппозиция без ее участия сформировать исполнительную власть не сможет.

Некоторые исследователи особо выделяют наличие у доминантной партии привилегированного доступа к основным кадровым назначениям в исполнительной и законодательной сферах [ibidem]. Кроме того, критерий доминантности партии имеет не только внешнее проявление (нахождение у власти), но и внутреннее - способность партии осуществлять эффективный политический выбор и принимать политические решения [Green 2010a: 809]. Наконец, проявляется доминантность эффективно и в идеологической сфере: программные установки доминантной партии определяют или оказывают решающее воздействие на общественный дискурс.

Имеются также критерии оценки системы доминантной партии с точки зрения ее субъективного восприятия со стороны избирателей. По мнению П. Данливи, партию можно признать доминантной, если она отвечает трем критериям: избиратели особо выделяют данную партию среди прочих по критерию эффективности; партия имеет привилегированное идеологическое поле (“защищенную” нишу), в которой никакая другая партия не может составить ей конкуренцию в борьбе за голоса избирателей; партия имеет более широкие возможности апеллирования к избирателям, чем ее конку- 
ренты [Dunleavy 2010: 27]. Данный подход означает принцип особого места доминантной партии в общественно-политической жизни страны с позиций электоральной привлекательности.

\section{ДОМИНАНТНЫЕ ПАРТИИ И НОРМЫ ДЕМОКРАТИИ}

Феномен доминантных партий присутствует в странах как с демократическими, так и с авторитарными режимами. Возникает вопрос о дифференциации доминантных партий в зависимости от типа режима, который они представляют. Однако классификация систем доминантной партии по признаку авторитарности власти сталкивается с большими затруднениями, поскольку даже в демократических режимах такая партия нередко прибегает к широкому диапазону манипуляций для победы в открытых многопартийных выборах.

Обоснованным представляется предложенное М. Богаардсом разделение систем доминантных партий на те, в которых правят доминантные партии и те, где господствуют авторитарные доминантные партии [Bogaards 2004: 178]. В системе доминантной партии (ДП) политические требования, социальные ожидания и проявления общественного недовольства обеспечены адекватным уровнем представительства и защиты, как в политике центрального правительства, так и в рядах доминантной партии. Инструментарий методов воздействия на избирателей в распоряжении доминантной партии, как правило, включает относительно мягкие формы электорального манипулирования, и прежде всего клиентелизм и партикуляристскую политику (pork-barrel politics).

В свою очередь, система авторитарной доминантной партии (АДП), более характерная для политических режимов с авторитарными формами правления, присутствует там, где однопартийное доминирование обеспечивается недемократическими средствами. Доминантная партия в таких режимах не допускает свободной конкуренции, а смена власти представляет собой лишь теоретическую возможность. Методы удержания власти АДП известны: это прямое насилие, запугивание избирателей, электоральные фальсификации, систематическое исключение определенных сил оппозиции из сферы политического участия через систему резервирования парламентских мандатов, использование преференциальных избирательных норм и иных правовых и административных ограничений избирательных прав, свободы слова, печати, собраний, свободы проведения избирательных кампаний и т.д.

Вместе с тем в системах доминантной партии и авторитарной доминантной партии наблюдаются и сходные черты. К их числу К. Грин относит прежде всего наличие “политии со значимыми выборами” [Greene 2010a: 809]. В это понятие он включает такую систему, при которой глава исполнительной власти и законодательное собрание определяются в ходе открытых регулярных выборов и не могут быть распущены или уволены исполнительной властью без достаточных на то оснований; силам оппозиции разрешено формировать независимые партии и участвовать в выборах; правящая партия не прибегает на выборах к фальсификациям, без использования которых ее власть была бы невозможна [ibid.: 810].

Следует отметить, что доминантность партии в электоральной сфере не может служить единственно значимой характеристикой для оценки роли и значения этой партии в правительстве и социуме, поскольку имеется множе- 
ство факторов доминантности, никак не связанных с уровнем электоральной поддержки. Например, популистская партия, получив на выборах подавляющее большинство голосов, может быть лишена рычагов экономического влияния, в результате чего у нее оказываются связанными руки в социальной сфере, даже несмотря на отсутствие конкурентов в парламенте. К тому же следует учесть, что избиратели, проголосовавшие за эту партию на выборах, могут выступать против правительственного курса по определенным вопросам социальной и экономической политики.

Таким образом, доминантность партии власти, ограниченная лишь сферами парламентской или электоральной политики, носит весьма условный характер. Электорально доминантная партия сталкивается с множеством переменных, ограничивающих ее власть, как только она предпринимает попытку реализовать преимущества своего доминантного положения за пределами парламента. В числе таких переменных - политическое влияние бюрократии, роль и значение иных непартийных акторов в системе принятия государственных решений, включая общественные институты, организации деловых кругов и т.д. По этой причине комплексное исследование доминантности должно охватывать не только электоральную сферу, но и различные аспекты общественно-политической жизни. Имеется и иерархия "этажей" доминантности: она может проявляться на общенациональном, субнациональном и межпартийном уровнях.

В работах некоторых политологов доминантность партии (равно как и однопартийность в политической системе) определяется как угроза демократии [Suttner 2006: 277]. Между тем доминантность партии как таковую трудно считать ключевой характеристикой конкретного вида политического режима; сам факт наличия системы доминантной партии не может служить основанием для выводов относительно соответствия или несоответствия такого режима нормам демократии. Скорее, допустимо лишь с осторожностью ассоциировать политическое доминирование партии со сложившейся в стране моделью демократии. Подход к феномену доминантности в значительной степени зависит от характеристик субъекта доминантности, а также от того, какие отношения выстроены данным субъектом с прочими государствами, институтами и даже отдельными индивидуумами.

\section{ФАКТОРЫ УСТОЙЧИВОСТИ СИСТЕМ ДОМИНАНТНЫХ ПАРТИЙ}

Следующий вопрос, который привлекает исследовательский интерес каковы факторы долгосрочности и стабильности систем доминантных партий?

Начинать следует, пожалуй, с исторических факторов. Доминантные партии могут играть ключевую роль в основании государства, либо иметь особые “заслуги” в установлении либеральной демократии или государства социального благосостояния. Такой репутационный ресурс в демократическом государстве способствует укреплению стабильности политического режима, особенно в периоды политических и экономических кризисов (АНК в Южной Африке, ИНК в Индии, СДП в Швеции и т.д.). Однако с течением времени репутационный ресурс истощается, особенно если речь идет о персоналистском режиме, основанном на харизме лидера (голлистская Франция 1958-1981 гг.). Важным фактором доминантности выступает также способность правящей партии эффективно использовать преимущества избирательной системы. Во 
многих странах с наибольшей для себя пользой доминантные партии проводят выборы в округах непропорционального представительства, где практикуются смешанные и параллельные системы голосования. Классический пример Япония: система полиноминальных округов в реальности представляла в период холодной войны явные преимущества доминантной партии в лице ЛДП.

Имея устойчивые связи с наиболее состоятельными социальными группами и крупнейшими корпорациями, направляющими в политическую сферу наибольший объем пожертвований, доминантные партии располагают привилегированным доступом к финансовым ресурсам, который позволяет им лучше других партий проводить финансовое обеспечение избирательных кампаний. Существенно эффективнее у доминантных партий и связи с ключевыми социальными группами или группами давления, обеспечивающими их важными организационными преимуществами в конструировании собственного социального капитала; к таковым относятся, например, религиозные и профсоюзные структуры. Уместно вспомнить о связях итальянского ХДС с католической церковью или о поддержке Демократической партии Японии крупнейшими профцентрами страны. В некоторых случаях ключевое значение приобретает связь доминантной партии с превалирующей этнической или языковой социальной группой. Важной характеристикой систем доминантной партии выступает также привилегированный доступ партии власти к медиа-ресурсам, включая те из них, что предоставляются крупнейшими частными медийными группами.

Различия в социальной базе, идеологической ориентации, типах организации, методах деятельности и электоральной практике дали М. Касснеру основания разделить доминантные партии на партии элитарного типа, массовые партии, этноцентричные партии, электоральные партии и партии - общественные движения. Исследуя партии по критериям их структуры (организация), функций (идеология) и политического поведения (деятельность), германский исследователь приходит к выводу о том, что влияние доминантных партий на демократию в мультикультурных обществах может быть самым разным: "Некоторые обеспечивают интеграцию населения в политическую систему, некоторые создают дезинтеграционный эффект. Некоторые трансформируют политическую систему в полноценную демократию, тогда как некоторые прокладывают путь к авторитарной системе” [Kaßner 2014: 34].

Что касается партийной идеологии, доминантная партия может занимать любую удобную в конъюнктурном отношении идеологическую позицию, даже если это влечет за собой риск отпугнуть часть избирателей. П. Данливи указывал, что доминантная партия имеет защищенный слой избирателей, который будет поддерживать ее вне зависимости от занимаемых ей идеологических позиций, даже несмотря на то, что она может потерять существенную часть голосов, находящихся на периферии этого слоя [Dunleavy 2010: 13]. Иными словами, доминантная партия как бы монополизирует "медианного" избирателя, который в прочих условиях переметнулся бы к другим партиям с понятной ему идеологической платформой. Даже в случае поражения на выборах она имеет достаточно преимуществ, чтобы вернуть себе ключевое положение в парламенте.

Справедливым будет замечание П. Данливи о том, что указанные факторы доминантности можно найти и в недоминантных (полицентрических) 
политических системах [ibid.: 14]. Однако для систем доминантных партий характерно то, что эти факторы действуют в совокупности, предоставляя доминантным партиям многослойную защиту за счет предоставляемого ими кумулятивного эффекта. Кроме того, изложенные факторы предоставляют наибольшие преимущества именно доминантной партии, тогда как оппозиция не может воспользоваться ими в полной мере.

\section{ПРИВИЛЕГИРОВАННЫЙ ДОСТУП К РЕСУРСАМ И КЛИЕНТЕЛИЗМ}

Исследования систем доминантной партии традиционно проводятся в рамках хорошо известной демократической парадигмы, в рамках которой приоритет отдается критерию соответствия или несоответствия нормам демократии. Определенным недостатком этого дискурса является чрезмерное внимание, уделяемое самой системе доминантной партии как методу организации власти, при недооценке места и роли оппозиционных партий как оппонентов партии власти. В реальности невозможно отделить вопрос о доминантности одной партии от проблемы слабости (и оппозиционности) ее оппонентов. Иными словами, доминантность партии власти в числе прочего определяется проблемами противостоящего лагеря: имеются конкретные причины, по которым оппозиционные партии могут никогда не стать правящими [Suttner 2006: 281]. Можно заключить, что партии становятся доминантными не просто потому, что они долгое время и без перерывов удерживают власть, но и потому, что они имеют длительное преимущество в эффективности над своими соперниками.

Известно, что доминантные партии имеют более прочное положение в системе власти за счет консолидации элит. Сильные правящие партии способны обуздать амбиции элиты и объединить разрозненные социальные силы, которые в противном случае образовали бы разрозненные коалиции. Консолидация элит отвечает интересам политических руководителей, продлевая временной отрезок, в течение которого они могут реализовывать свое влияние на общество; тем самым она укрепляет способность партии снизить недовольство в ее рядах. Как только политики начинают ощущать коллективные преимущества, которые доминантная партия приносит им лично, они становятся более склонными поддерживать ее деятельность [Brownlee 2007: 39].

Один из механизмов такой консолидации проявляется в налаженной системе обратной связи доминантной партии с политической элитой. Большой интерес в этой связи привлекает к себе вопрос о ресурсной составляющей власти доминантных партий.

Как в демократических, так и в авторитарных режимах доминантные партии выстраивают свою систему правления, основанную на асимметрично высокой доле получаемых ресурсов. Сильный перевес в ресурсах наряду с возможностью повышать издержки участия акторов в конкурирующих партиях представляют собой два важнейших преимущества доминантной партии перед оппозицией [Порошин 2011: 160]. Как отмечал К. Грин, “'когда представители партии власти имеют доступ и могут распоряжаться этими публичными ресурсами для нужд своей партии, они могут превзойти своих конкурентов в уровне затрат и ... сделать открытую конкуренцию настолько несправедливой, что фактически они выиграют выборы еще до их начала" [Greene 2010a: 808].

Многие авторы придерживаются мнения, что именно монополия на ресурсы обеспечивает монополию на политическую власть [Lipset 1963, 
Schumpeter 1947]. Регулируя и направляя процесс распределения трофеев, карьерных возможностей и прерогатив принятия политических решений, доминантные партии предоставляют элитам основания верить в то, что они получат достаточную долю этих благ в будущем, что в свою очередь обеспечивает им лояльность элит. Например, во многих системах доминантных партий неукоснительно действуют определенные принципы распределения трофеев в качестве награды за лояльность, и, наоборот, неотвратимости наказания за нелояльность в виде отказа от доступа к этим трофеям. В противоположность этому элиты, не имеющие таких институализированных механизмов распределения трофеев и лишенные полноценных гарантий доступа к ним, имеют больше стимулов для проявления нелояльности к правителю, в том числе в форме заговора или государственного переворота [Reuter, Turovsky 2012: 664]. Подтверждением тому служит, в частности, тот факт, что бегство представителей элиты в противоположный лагерь - одна из главных причин падения авторитарных режимов.

Важный момент, связанный с ресурсной рентой, заключается в наличии у доминантных партий значимых ресурсов электоральной мобилизации, отсутствующих у оппозиционных партий. Ресурсные рычаги позволяют доминантным партиям прибегать к массовой фальсификации на выборах или к жестким репрессивным методам в отношении своих политических противников. Вместе с тем именно ресурсная рента позволяет существовать системам авторитарных доминантных партий в качестве режимов с определенной степенью конкурентности, оставляющей значимую нишу оппозиционным силам, в противоположность полностью закрытым авторитарным режимам, в которых все возможности для выражения недовольства оказываются полностью перекрытыми. Поэтому власть доминантной партии оказывается под угрозой, когда доступ партии власти к публичным ресурсам существенно ограничивается, а оппозиционные партии получают равные с ней возможности конкурировать за голоса избирателей.

Ресурсы распределяются через различные компании сферы общественного предпринимательства, а также те сектора экономики, которые в наибольшей степени зависят от бюджетного финансирования. Речь может идти об особых связях государства с бизнесом, ведущих в “серую” и откровенно криминальную зону - это и “откаты”, и поборы, и незаконные политические пожертвования в обмен на патронаж государства, бенефициарность в распределении контрактов и т.д.

Вопрос о ресурсной ренте тесно связан с проблемой клиентелизма. Клиентелизм, как и партикуляристская политика, - выражение фаворитизма, намеренно используемого партией власти в качестве стратегии политической мобилизации. В условиях, когда масштабы и процессы партикуляристской политики делают этот феномен видимым и, соответственно, подверженным общественным дебатам, данная практика отвечает стандартам демократического процесса, даже несмотря на те негативные эффекты, которые партикуляризм может оказывать на общественное благо [Trantidis 2015: 123].

Клиентелизм выступает продуктом двух взаимосвязанных процессов конкуренции за политическую власть и конкуренции за ресурсы, ей распределяемые. Благодаря относительно открытому электоральному процессу в демократических режимах инструментарий “силовых” политических методов, 
имеющихся в арсенале доминантных партий, оказывается недостаточным для обеспечения власти в случае падения их популярности. Это связано с тем обстоятельством, что в демократических режимах, в отличие от авторитарных, доминантные партии находятся в сильной зависимости от электоральной поддержки, для обеспечения которой они склонны использовать “мягкие” формы электорального манипулирования. В этих условиях именно клиентелизм нередко выступает в качестве центральной, если не основной, стратегии доминантных партий, с помощью которой они имеют возможность увеличить свою популярность и противостоять оппозиции [Bogaards 2004: 178].

В качестве базовой стратегии доминантных партий клиентелизм присутствует во многих страновых кейсах: Японии, Мексике, Израиле, Малайзии, Тайване, а также России и иных государствах бывшего СССР. Во многих случаях “мягкий” клиентелизм дополняется жесткими формами электоральной мобилизации, в том числе прямым запугиванием избирателей.

Клиентелизм проявляется в исключительно широком диапазоне форм. Кандидаты на выборах покупают голоса; определенные округа получают преимущества от общественных работ, полученных в результате лоббистских усилий их представителей в органах власти; правящие партии подкупают деятелей оппозиции; друзья и сторонники партий власти получают карьерные возможности; граждане формируют индивидуальные или групповые отношения с партией власти, которые они используют для получения различных товаров или услуг и т.д. [Hilgers 2011: 572]. Нередко общим знаменателем этого феномена выступает партикуляристская политика. В некоторых случаях она настолько искажает политическую конкуренцию, что поведение избирателей, существенно отличаясь от нормативного, становится важнейшим фактором удержания власти доминантной партией. При этом устойчивый и длительный характер клиентелистских отношений укрепляет степень подотчетности партии власти ее клиентам, пусть и проявляющуюся в искаженном виде. Такая подотчетность создает гораздо больше стимулов для лояльности, нежели простая покупка голосов [ibid.: 578].

Дополнительную сложность для исследования клиентелизма представляет неупорядоченность и правовая неоформленность этой практики, хаотичность в использовании правящей партией методов авторитарного контроля, включая формальные и неформальные ограничения на доступ оппонентов к ресурсам, СМИ и судебной системе. На этом фоне затруднительным становится применение классических методов политологического анализа систем доминантной партии, в том числе классификация клиентелистской политики. По этой причине клиентелизм рассматривается в первую очередь как “контекстуально встроенный феномен” [Hilgers 2012: 4], проявляющийся в самых разнообразных политических условиях.

Контекстуальность клиентелизма связана с социально-экономическими и политическими условиями, в которых он может стать фактором влияния на партисипативное поведение граждан (или, наоборот, не стать таковым). Так, миноритарные акторы, не имеющие доступа к различным инструментам клиентелистской политики (например, малые партии, индивидуальные кандидаты из числа новичков и т.д.), вынуждены считаться с крайне высокими неформальными барьерами для восхождения на электоральное поле. В результате в структуре политического представительства различных обществен- 
ных слоев возникают определенные искажения. Кроме того, клиентелизм сокращает пространство для равного и справедливого соревнования между политическими партиями по вопросам, затрагивающим их идейно-политические принципы [Greene 2010b]. Партии оппозиции оказываются не в состоянии рекрутировать сторонников и активистов из-за увеличения организационных затрат до того уровня, при котором конкуренция с правящей партией становится бессмысленным делом. В этом смысле можно полагать, что клиентелизм, снижая уровень политической конкурентности режима до несущественного, по сути, становится ключевым фактором его перерождения в сторону авторитаризма.

Эффективность клиентелизма в арсенале доминантной партии определяется не только ее способностью награждать клиентов, но и имеющейся у нее возможностью наказывать своих оппонентов путем их дискриминации и применения к ним прямых материальных санкций, вплоть до исключения из распределительных цепочек, доступных лишь кооптированным социальным или экономическим акторам. Меры “негативного воздействия" могут включать существенные задержки или прямой саботаж в оказании государственных услуг, отказы в предоставлении кредитов со стороны банков, находящихся под государственным контролем, дискриминационные меры налогового контроля и т.д.

Помимо материальных (и прежде всего, финансовых) ресурсов, доминантное положение дает партии власти мощные кадровые ресурсы, а именно большое количество патронажных постов, которые можно использовать для награждения своих сторонников при одновременном дискриминировании оппонентов. Кадры, имеющие институциональные гарантии для продвижения вверх, как правило, больше заинтересованны в поддержке существующего режима, нежели в случае, если таких гарантий нет или их недостаточно. Гарантированные возможности для карьерного роста, предоставляющие правящей элите ощущение психологического комфорта, составляют одну из причин прочности и долговечности режимов доминантных партий.

При этом институциональные нормы, касающиеся бенефициарного положения лоялистов, как правило, являются некодифицированными и чаще всего носят неформальный характер. Лояльность элит поэтому в значительной степени зиждется на обещаниях диктаторов. Вместе с тем слабость этого механизма заключается в возможности невыполнения диктаторами своих обещаний, появлении в этой связи “перебежчиков”, усилении нелояльности и, соответственно, в риске дестабилизации власти. На этом фоне роль доминантных партий неоценима: правители могут ослабить остроту проблемы реализации обещаний путем делегирования ей хотя бы части управленческих рычагов по распределению трофеев. Передавая партии прерогативу кадровых назначений на ключевые посты в правительстве, диктаторы в долгосрочном плане обеспечивают весомыми гарантиями власти и доступом к трофеям тех, кто сделал ставку на существующие институты, в противоположность тем, кто больше надеется на подрывные коалиции [Magaloni 2008: 716]. Правящая партия вырабатывает общие правила и нормы, касающиеся распределения трофеев, что снижает среди элит ощущение неопределенности и ограничивает проявления нелояльности. Считается, что в сбалансированной системе партийного доминирования диктатор не может нарушать нормы распределения 
трофеев, поскольку подобное вмешательство может привести к дезертирству части элиты [Reuter, Turovsky 2012: 665].

Политики должны уметь “выколачивать" патронажные бенефиции из государства; отсюда отношения между политическими партиями и бюрократами приобретают ключевое значение в определении политиками своего поведения [Shefter 1994: XII]. На этом фоне важным условием для бесперебойного функционирования практики клиентелизма выступает политический контроль доминантной партии над бюрократией. Этот контроль обеспечивается путем немеритократических (патронажных) кадровых назначений, а также удаления несогласных и неблагонадежных даже из “долгих списков” кадровых резервов. Патронажные методы делают бюрократов менее склонными действовать как "ночные сторожи”, защищающие общественное благо от набегов “безответственных политиков” [Greene 2010: 812]. Кроме того, доминантные партии имеют возможность использовать в своих интересах (например, для проведения избирательных кампаний) инфраструктуру государственных органов, включая офисные помещения, средства транспорта, связи и коммуникации. В некоторых случаях работники государственных органов могут даже привлекаться для информационно-пропагандистской работы правящей партии. В свою очередь, партии оппозиции, имеющие низкую долю таких ресурсов, оказываются неспособными привлечь достаточное число голосов избирателей для победы на выборах.

Отвечает ли практика клиентелизма стандартам демократии? С одной стороны, клиентелистские обмены протекают в непубличной форме и сконструированы именно для того, чтобы не допустить прозрачности в деле распределения общественных ресурсов. Однако отношения между патронами и клиентами отражают консенсуальное соглашение между ними, согласно которому обе стороны получают существенные выгоды. Поэтому представить дело можно и так, что клиентелизм расширяет выбор граждан в их стремлении получить дополнительный доступ к ресурсам, предоставляя им новые возможности получения вознаграждения за электоральную и политическую активность.

Особенно следует обратить внимание на то обстоятельство, что клиентелистские стимулы не заставляют граждан менять поведение против своей воли. Клиенты пользуются правом выбора - принять или отвергнуть предложенную награду. Поэтому влияние клиентелизма на политическое поведение нельзя приравнять к одной из форм типичного авторитарного контроля. Таким образом, партикуляристский тип распределения ресурсов может вносить определенный вклад в теорию демократии. Вместе с тем на том этапе, когда привносимая клиентелизмом дискриминация достигает такого уровня интенсивности, который лишает клиентов права выбора, клиентелизм работает аналогично силе принуждения и уже не соответствует нормам демократии [Trantidis 2015: 126]. Активное использование клиентелизма в системах доминантных партий в высокополитизированной экономике становится поэтому формой насилия и прямым ограничением политической свободы.

$$
* * *
$$

Возникает вопрос о практическом применении наработанной в мировой политической науке методологии подходов к феномену доминантных партий. Особенно высокую степень актуальности этот инструментарий приобретает 
применительно к современной России, где указанный феномен имеет зачастую гипертрофированные формы, проявляясь в различных общественно значимых контекстах. Могут быть самые разные точки зрения на то, относится ли "Единая Россия" к числу авторитарных доминантных партий или это просто доминантная партия персоналистского типа; является ли современная Россия политией со значимыми выборами, которые в случае смены общественных настроений могут всерьез изменить политический ландшафт, или она таковой не является; имеет ли правящая партия в России “защищенную” идеологическую нишу, или высокий уровень ее электоральной поддержки отражает лишь личную харизму национального лидера. Наконец, крайне любопытен и вопрос о том, обеспечивает ли доминантная партия в России реальную интеграцию населения в политическую систему, или же, наоборот, результатом ее правления выступает отчуждение избирателей от политических и бюрократических институтов государственной власти.

Аналогичные вопросы могут возникнуть и в иных страновых кейсах, где доминантность правящей партии может иметь существенную структурноорганизационную, партийно-политическую, идеологическую, электоральную, социально-психологическую, культурно-историческую и иную специфику. Трудность заключается и в существенной гетерогенности данного феномена, волатильности критериев доминантности, наличии повышенной динамики партийно-политической ситуации в условиях глобализации; тем самым, задача построения стройной и последовательной методологии исследования феномена доминантных партий оказывается делом крайне сложным, если не сказать практически неосуществимым.

Порошин А.В. 2011. Авторитарные режимы с доминантной партией: основные свойства и факторы устойчивости. - Бизнес. Общество. Власть. № 7. С. 156-178.

Bogaards M. 2004. Counting Parties and Identifying Dominant Party Systems in Africa. - European Journal of Political Research. Vol. 43. P. 173-197. DOI: http://dx.doi. org/10.1177/1354068807083825

Brownlee J. 2007. Authoritarianism in an Age of Democratization. Cambridge: Cambridge University Press. 280 p.

Cox G. 1997. Making Votes Count. Cambridge, UK: Cambridge University Press. 344 p.

Dunleavy P. 2010. Rethinking Dominant Party Systems. - Dominant Political Parties and Democracy: Concepts, Measures, Cases and Comparisons. Ed. by M. Bogaards, F. Boucek. L.: Routledge. P. 23-44.

Greene K.F. 2010a. The Political Economy of Authoritarian Single-Party Dominance. -Comparative Political Studies. Vol. 43. No. 7. P. 807-834. DOI: http://dx.doi. org/10.1177/0010414009332462

Greene K.F. 2010b. Resource-Theory of Single-Party Dominance: The PRI in Mexico. Dominant Political Parties and Democracy. Ed. by M. Bogaards, F. Boucek. L.: Routledge. P. 155-174.

Hilgers T. 2011. Clientelism and Conceptual Stretching: Differentiating Among Concepts and Among Analytical Levels. - Theory and Society. Vol. 40. No. 5. P. 567-588. DOI: http:// dx.doi.org/10.1007/s11186-011-9152-6

Hilgers T. 2012. Democratic Processes, Clientelistic Relationships, and the Material Goods Problem. - Clientelism in Everyday Latin American Politics. Ed. by T. Hilgers. Palgrave Macmillan US. P. 3-22. 
Kaßner M. 2014. The Influence of the Type of Dominant Party on Democracy. A Comparison between South Africa and Malaysia. Springer. $386 \mathrm{p}$.

Lipset S. 1963. Political Man: The Social Bases of Politics. N.Y.: Doubleday. 477 p.

Magaloni B. 2008. Credible Power-Sharing and the Longevity of Authoritarian Rule. - Comparative Political Studies. Vol. 41 No. 4-5. P. 715-741. DOI: http://dx.doi. org/10.1177/0010414007313124

Pempel T. 1999. Foreword. - The Awkward Embrace. Ed. by H. Giliomee, C. Simkins. Cape Town: Tafelberg. P. VI-IX.

Reuter O., Turovsky R. 2012. Dominant Party Rule and Legislative Leadership in Authoritarian Regimes. - Party Politics. Vol. 20. No. 5. P. 663-674. DOI: http://dx.doi. org/10.1177/1354068812448689

Sartori G. 1976. Parties and Party Systems: A Framework for Analysis. Vol. 1. N.Y.: Cambridge University Press. 343 p.

Schumpeter J. 1947.Capitalism, Socialism, and Democracy. N.Y.: Harper. 178 p.

Shefter M. 1994. Political Parties and the State: The American Historical Experience. Princeton, NJ: Princeton University Press. 316 p.

Suttner R. 2006. Party Dominance 'Theory': Of What Value? - Politikon. Vol. 33. No. 3. P. 277-297. DOI: http://dx.doi.org/10.1080/02589340601122901

Trantidis A. 2015. Clientelism and the Classification of Dominant Party Systems. Democratization. Vol. 22. No. 1. P. 113-133. DOI: http://dx.doi.org/10.1080/13510347.201 3.825608

DOI: $10.17976 /$ jpps/2017.03.07

\title{
DOMINANT PARTY SYSTEMS: SOME APPROACHES TO THE METHODOLOGY OF THE STUDY
}

\section{D.V. Streltsov ${ }^{1}$}

${ }^{1}$ Moscow State Institute of International Relations (University), MFA of Russia. Moscow, Russia

STRELTSOV Dmitry Viktorovich, Dr. Sci. (Hist.), Head of Department, Professor, Moscow State Institute of International Relations (University), MFA of Russia. Email: d.streltsov@inno.mgimo.ru

Streltsov D.V. Dominant Party Systems: Some Approaches to the Methodology of the Study. - Polis. Political Studies. 2017. No. 3. P. 105 -118. (In Russ.) DOI: https://doi.org/10.17976/jpps/2017.03.07

Acknowledgments. This article was prepared with financial support provided by the Russian Foundation for Humanities (project No. 16-01-50085 “The 1955 System": The Political Power in Japan During the Cold War")

Received: 10.10.2016. Accepted: 01.02.2017

\begin{abstract}
The article examines the key criteria for the concept of the dominant party, such as its ability to consistently and steadily win the elections, the significant duration of its stay in power, as well as its personnel control of the Cabinet of ministers. In the sociopolitical discourse the dominant party enjoys a privileged ideological position and has more opportunities compared to its competitors to appeal to voters. Along with that the party dominance reveals itself not only in its external manifestation (the stay in power), but also in the substantial one - the ability to exercise an effective political choice. The article analyzes the factors of sustainability of the dominant party systems: the historical merits of the dominant party; the ruling party's ability to effectively take advantage of the electoral system; its strong relationships with the most affluent social groups and major corporations, as well as with the predominant ethnic or linguistic social groups; a privileged access of the ruling party to media resources. These factors are also effective in the polycentric political systems without any dominant party. However, under the dominant party systems they manifest themselves in a complex way, providing the ruling camp with a multi-layered protection due to a synergy effect. Particular attention is paid to the phenomenon of clientelism, widely used by the ruling party as a strategy of political mobilization. While the scope and durability of the porkbarrel politics make this phenomenon socially significant and, accordingly, subject to public control,
\end{abstract}


clientelism complies with the standards of democratic process, even in spite of its possible negative effects on the public good. However, if discrimination arose by clientelism reaches the level that denies clients the right to choose, this is certainly not consistent with the rules of democracy.

Keywords: dominant party; clientelism; the pork-barrel politics; competition; democracy; access to resources; patronage; meaningful elections; contextually embedded phenomenon.

\section{References}

Bogaards M. Counting Parties and Identifying Dominant Party Systems in Africa. - European Journal of Political Research. 2004. Vol. 43. P. 173-197. DOI: http://dx.doi.org/10.1177/1354068807083825

Brownlee J. Authoritarianism in an Age of Democratization. Cambridge: Cambridge University Press. 2007. $280 \mathrm{p}$.

Cox G. Making Votes Count. Cambridge, UK: Cambridge University Press. 1997. 344 p.

Dunleavy P. Rethinking Dominant Party Systems. - Dominant Political Parties and Democracy: Concepts, Measures, Cases and Comparisons. Ed. by M. Bogaards, F. Boucek. L.: Routledge. 2010. P. 23-44.

Greene K.F. The Political Economy of Authoritarian Single-Party Dominance. - Comparative Political Studies. 2010. Vol. 43. No. 7. P. 807-834. DOI: http://dx.doi.org/10.1177/0010414009332462

Greene K.F. Resource-Theory of Single-Party Dominance: The PRI in Mexico. - Dominant Political Parties and Democracy. Ed. by M. Bogaards, F. Boucek. L.: Routledge. 2010. P. 155-174.

Hilgers T. Clientelism and Conceptual Stretching: Differentiating Among Concepts and Among Analytical Levels. -Theory and Society. 2011. Vol. 40. No. 5. P.567-588. DOI: http://dx.doi.org/ 10.1007/ s11186-011-9152-6

Hilgers T. Democratic Processes, Clientelistic Relationships, and the Material Goods Problem. Clientelism in Everyday Latin American Politics. Ed. By T.Hilgers. Palgrave Macmillan US. 2012. P. 3-22.

Kaßner M. The Influence of the Type of Dominant Party on Democracy. A Comparison Between South Africa and Malaysia. Springer. 2014. 386 p.

Lipset S. Political Man: The Social Bases of Politics. NY: Doubleday. 1963. 477 p.

Magaloni B. Credible Power-Sharing and the Longevity of Authoritarian Rule. - Comparative Political Studies. 2008. Vol. 41. No.4-5. P. 715-741. DOI: http://dx.doi.org/10.1177/0010414007313124

Pempel T. Foreword. - The Awkward Embrace. Ed. by H. Giliomee, C. Simkins. Cape Town: Tafelberg. 1999. P. VI-IX.

Poroshin A.V. Dominant Party Authoritarian Regimes: Key Characteristics and Reasons for Stability. Business. Society. Government. 2011. No. 7. P. 156-178. (In Russ.)

Reuter O., Turovsky R. Dominant Party Rule and Legislative Leadership in Authoritarian Regimes. Party Politics. 2012. Vol. 20. No. 5. P. 663-674. DOI: http://dx.doi.org/10.1177/1354068812448689

Sartori G. Parties and Party Systems: A Framework for Analysis. Vol. 1. N.Y.: Cambridge University Press. 1976. $343 \mathrm{p}$.

Schumpeter J. Capitalism, Socialism, and Democracy. N.Y.: Harper. 1947. 178 p.

Shefter M. Political Parties and the State: The American Historical Experience. Princeton, NJ: Princeton University Press. 1994. 316 p.

Suttner R. Party Dominance 'Theory': Of What Value? - Politikon. 2006. Vol. 33. No. 3. P. 277-297. DOI: http://dx.doi.org/10.1080/02589340601122901

Trantidis A. Clientelism and the Classification of Dominant Party Systems. - Democratization. 2015. Vol. 22. No. 1. P. 113-133. DOI: http://dx.doi.org/10.1080/13510347.2013.825608 